\title{
Corn silage from corn treated with foliar fungicide and performance of Holstein cows
}

\author{
K. J. Haerr, ${ }^{*}$ N. M. Lopes, ${ }^{*} \dagger$ M. N. Pereira,† G. M. Fellows, $\ddagger$ and F. C. Cardoso*1 \\ *Department of Animal Sciences, University of Illinois, Urbana 61801 \\ †Departamento de Zootecnia, Universidade Federal de Lavras, Lavras, MG, Brazil 37200-000 \\ łBASF Corporation, Research Triangle Park, NC 27709
}

\section{ABSTRACT}

Foliar fungicide application to corn plants is used in corn aimed for corn silage in the dairy industry, but questions regarding frequency of application and its effect on corn silage quality and feed conversion when fed to dairy cows remain prevalent. The objective of this study was to evaluate the effects of various foliar fungicide applications to corn on dry matter intake (DMI), milk production, and milk composition when fed to dairy cows. Sixty-four Holstein cows with parity 2.5 $\pm 1.5,653 \pm 80 \mathrm{~kg}$ of body weight, and $161 \pm 51 \mathrm{~d}$ in milk were blocked and randomly assigned to 1 of 4 corn silage treatments (total mixed ration with $35 \%$ of the dry matter as corn silage). Treatments were as follows: control (CON), corn silage with no applications of foliar fungicide; treatment 1 (1X), corn silage from corn that received 1 application of pyraclostrobin (PYR) foliar fungicide (Headline; BASF Corp.) at corn vegetative stage 5 ; treatment $2(2 \mathrm{X})$, corn silage from corn that received the same application as $1 \mathrm{X}$ plus another application of a mixture of PYR and metconazole (Headline AMP; BASF Corp.) at corn reproductive stage 1 ("silking"); and treatment 3 (3X), corn silage from corn that received the same applications as $2 \mathrm{X}$ as well as a third application of PYR and metconazole at reproductive stage 3 ("milky kernel"). Corn was harvested at about $32 \%$ dry matter and $3 / 4$ milk line stage of kernel development and ensiled for $200 \mathrm{~d}$. Treatments were fed to cows for $5 \mathrm{wk}$, with the last week being used for statistical inferences. Week -1 was used as a covariate in the statistical analysis. Dry matter intake tended to be lower for cows fed corn silage treated with fungicide than CON $(23.8,23.0,19.5$, and $21.3 \mathrm{~kg}$ for CON, 1X, $2 \mathrm{X}$, and $3 \mathrm{X}$, respectively). A linear treatment effect for DMI was observed, with DMI decreasing as foliar

Received May 29, 2015.

Accepted August 26, 2015.

${ }^{1}$ Corresponding author: cardoso2@illinois.edu fungicide applications increased. Treatments CON, 1X, $2 \mathrm{X}$, and $3 \mathrm{X}$ did not differ for milk yield $(34.5,34.5$, 34.2 , and $34.4 \mathrm{~kg} / \mathrm{d}$, respectively); however, a trend for increased feed conversion represented by fat-corrected milk/DMI (1.65 vs. 1.47) and energy-corrected milk/ DMI (1.60 vs. 1.43) was noted for cows fed corn silage with fungicide compared with CON. In conclusion, cows receiving corn silage treated with foliar fungicide had better conversion of feed dry matter to milk than those receiving CON silage.

Key words: milk yield, corn silage, foliar fungicide, feed conversion

\section{INTRODUCTION}

Corn silage is a major component of dairy rations, sometimes constituting more than $50 \%$ of total dietary DM. As prices of corn increase, producers are assessing more ways of improving corn. The use of foliar fungicides to efficiently increase corn yield for grain production has been studied in recent years (Wise and Mueller, 2011). A meta-analysis concluded that corn treated with a pyraclostrobin-based fungicide had a mean yield increase of $256 \mathrm{~kg} / \mathrm{ha}$ when compared with a control crop (Paul et al., 2011). Fungicides may cause changes in plant physiology that may be beneficial to plant nutritive quality (Venancio et al., 2009).

One of the primary factors affecting corn silage quality is NDF digestibility, as NDF makes up a major portion of corn silage (Allen et al., 2003). A one-unit increase in in vitro or in situ digestibility of corn silage NDF was associated with $0.25 \mathrm{~kg} / \mathrm{d}$ increase in $4 \%$ FCM yield (Oba and Allen, 1999). Fungal contamination may cause an increase in lignification of the fiber in plants and, therefore, decrease NDF digestibility (Yates et al., 1997). Another aspect of concern in corn silage quality is the availability and total content of starch (Teller et al., 2012). Bal et al. (2000) reported that processing whole-plant corn silage with a kernel processing method increased apparent total-tract starch digestibility by $4 \%$ compared with no kernel processing. However, using a meta-analysis approach, Ferraretto 
and Shaver (2012) reported that DMI was unaffected by kernel processing. Their study also reported an increase in milk production of $1 \mathrm{~kg} / \mathrm{d}$ when corn silage subjected to kernel processing using rollers was fed to Holstein cows. Damage to ears while in the field can cause a decrease in total starch content and an increase in fumonisin content in corn used for silage, which can decrease feed quality (Teller et al., 2012). In addition, damaged crop due to a fungal infection can increase defoliation and decrease the photosynthetic area on the plant. This has the potential to decrease both grain yield and starch content (Ward et al., 1997; Adee et al., 2005). Infestation by fungal colonies can also decrease corn silage quality and can pose a risk for the animals and people exposed to the feed (dos Santos et al., 2003; Richard et al., 2007). Some common mycotoxins in corn silage are aflatoxin, deoxynivalenol, zearalenone, T-2 toxins, fumonisin, and ochratoxin (Allen et al., 2003).

Foliar fungicide application on corn plants could affect milk production and farm overall profitability by increasing corn silage quality. Therefore, the objective of our study was to determine the effects of various fungicide applications to corn on DMI, milk production, and milk composition when it was fed to lactating dairy cows.

\section{MATERIALS AND METHODS}

\section{Corn}

The corn hybrid used for this study was LG2636 VT3P RIB (LG Seeds, Elmhurst, IL), which is a dualpurpose hybrid used for either grain or silage. It is advertised as 114-d maturity, with high yield potential, strong stalks, and high vigor. This hybrid is advertised as having a high level of resistance against northern corn leaf blight (caused by the fungus Exserohilum turcicum), southern corn leaf blight (caused by the fungus Bipolaris maydis), and gray leaf spot (caused by the fungus Cercospora zeae-maydis). This hybrid also contains transgenic traits that provide protection against corn earworm (Helicoverpa zea). Treatments were randomly assigned to four 0.8-ha plots and all corn was planted on June 5, 2013. Treatments were as follows: control $(\mathbf{C O N})$, corn received no foliar fungicide application; treatment $1(\mathbf{1 X})$, in which corn received 1 application of pyraclostrobin (PYR) foliar fungicide (Headline; BASF Corp.) at a rate of $0.11 \mathrm{~kg}$ of active ingredient (a.i.)/ha at corn vegetative stage 5 (V5; when 5 visible leaf collars can be seen; Mueller and Pope, 2009); treatment $2(\mathbf{2 X})$, in which corn received 2 applications of foliar fungicides, PYR at $0.11 \mathrm{~kg}$ of a.i./ha at corn stage V5, and a mixture of PYR + met- conazole (MET; Headline AMP; BASF Corp.) at 0.11 $+0.04 \mathrm{~kg}$ of a.i./ha at corn reproductive stage 1 (when silks are visible outside the husks; Mueller and Pope, 2009); and treatment $3(\mathbf{3 X})$, in which corn received 3 applications of foliar fungicide, PYR at $0.11 \mathrm{~kg}$ of a.i./ ha at corn stage V5, PYR + MET at $0.11+0.04 \mathrm{~kg}$ of a.i./ ha at corn reproductive stage 1 , and PYR + MET at $0.11+0.04 \mathrm{~kg}$ of a.i. $/$ ha at corn reproductive stage 3 (when kernel is yellow outside, whereas the inner fluid is now milky white due to accumulating starch; Mueller and Pope, 2009). The dates for fungicide application for first, second, and third applications were July 7, July 26, and August 13, 2013, respectively.

Corn foliar disease severity was evaluated throughout the growing season. Plots were evaluated at corn silk-emergence (August 2) and kernel-milk stage (August 16). Ten plants were arbitrarily selected within each plot for each evaluation date. For each selected plant, disease severity (percentage of leaf area) was estimated for the ear leaf, the leaf above the ear leaf, and the leaf below the ear leaf. Fungicide applications were made with a 4430 Case $\mathrm{IH}$ ground sprayer $(\mathrm{CNH}$ Industrial, London, UK) and applied at $27.27 \mathrm{~kg}$ of pressure using 73-60-110 10 VS nozzle tips at a volume of $348.5 \mathrm{~L} / \mathrm{ha}$. The sprayer was driven through all plots at each application timing, including those plots that did not receive a fungicide application, to account for any physical damage. For each plot, at least 3 samples of chopped corn were used in a composite sample to measure DM. Corn silage was harvested at $3 / 4$ milk line stage of kernel development and DM of 33, 30, 30, and $32.5 \%$ for $\mathrm{CON}, 1 \mathrm{X}, 2 \mathrm{X}$, and $3 \mathrm{X}$ treatments, respectively. The corn silage was harvested and processed over a period of $2 \mathrm{~d}$ using a New Holland FP240 forage chopper (CNH Industrial). The processer was set for a 1.9-cm theoretical length of chop, and a kernel processor was used to ensure mechanical processing of corn kernels. Chopped plant material was then transported to the storage site using an $\mathrm{H} \& \mathrm{P}$ forage wagon $(\mathrm{H} \&$ S Manufacturing Company Inc., Marshfield, WI) and ensiled in 2.74-m diameter bags with an AG Bagger (Ag Bag Systems, St. Nazianz, WI), using the DM of the silage to adjust the setting on the bagger to ensure adequate and uniform preservation of the corn silage. Corn silage was allowed to ferment for at least $200 \mathrm{~d}$ before opening. The trial finished $300 \mathrm{~d}$ postensiling.

\section{Animals}

All experimental procedures were approved by the University of Illinois (Urbana-Champaign) Institutional Animal Care and Use Committee. Sixty-four Holstein cows with parity $2.53 \pm 1.5,653+80 \mathrm{~kg}$ of 
Table 1. Ingredient composition of the lactation diet fed to cows throughout the experiment

\begin{tabular}{lc}
\hline Ingredient & \% of DM \\
\hline Alfalfa hay & 6.9 \\
Corn silage & 34.9 \\
Alfalfa silage & 6.1 \\
Cottonseed & 3.2 \\
Wet brewers grain & 8.1 \\
Dry ground corn grain & 25.0 \\
Soybean meal, 48\% CP & 2.6 \\
Expeller soybean meal ${ }^{2}$ & 1.2 \\
Soy hulls & 4.9 \\
Sodium bicarbonate & 0.81 \\
Limestone & 1.20 \\
Dicalcium phosphate & 0.29 \\
Calcium sulfate & 0.13 \\
Energy Booster $100^{3}$ & 1.50 \\
Biotin & 0.38 \\
Blood meal 85\% & 1.48 \\
Urea $_{\text {Potassium carbonate }}$ & 0.35 \\
Magnesium oxide & 0.30 \\
Salt (plain) & 0.13 \\
Mineral and vitamin mix & 5 \\
\hline
\end{tabular}

\footnotetext{
${ }^{1}$ All treatments fed at $34.9 \%$ corn silage DM.

${ }^{2}$ SoyPlus (West Central, Ralston, IA).

${ }^{3}$ Energy Booster 100 (Milk Specialties Global, Paris, IL); 98\% total FA and less than $2 \%$ unsaponifiable fat.

${ }^{4} 1 \mathrm{~g}$ of Rovimix Biotin (DSM, Heerlen, the Netherlands) contains 20 mg of biotin.

${ }^{5}$ Mineral and vitamin mix was formulated to contain $5 \% \mathrm{Mg}, 10 \% \mathrm{~S}$, $7.5 \% \mathrm{~K}, 2.0 \% \mathrm{Fe}, 3.0 \% \mathrm{Zn}, 3.0 \% \mathrm{Mn}, 5,000 \mathrm{mg} / \mathrm{kg}$ of $\mathrm{Cu}, 250 \mathrm{mg} / \mathrm{kg}$ of I, $40 \mathrm{mg} / \mathrm{kg}$ of Co, $150 \mathrm{mg} / \mathrm{kg}$ of Se, $2,200 \mathrm{kIU} / \mathrm{kg}$ of vitamin A, 660 $\mathrm{kIU} / \mathrm{kg}$ of vitamin $\mathrm{D}_{3}$, and $7,700 \mathrm{IU} / \mathrm{kg}$ of vitamin $\mathrm{E}$.
}

BW, and $161 \pm 51$ DIM were randomly selected and assigned to 1 of 4 treatments in a randomized complete block design. Cows were distributed into 16 blocks with regard to lactation number, previous lactation 305-d milk yield, and BCS to ensure that these variables had minimal chance of influencing the outcome variables of the study. The week before the start of the experiment (wk-1) was used to measure baseline values (covariate) for all applicable parameters. The next $4 \mathrm{wk}$ (wk 1 to 4) were considered an adjustment period to treatments, and data collected in wk 5 was used for treatment inferences on outcome variables of interest.

A lactation diet (Table 1) was fed to all cows to supply $100 \%$ of the NRC (2001) requirements for energy and all nutrients so that only the effects of dietary treatment during the lactation period differed. All cows received $34.9 \%$ of dietary DM as corn silage. The diet was fed once daily at $1400 \mathrm{~h}$. Cows were housed in tiestalls that met or exceeded space requirements as specified in the Ag Guide (FASS, 2010). Feed and water were available at all times. Temperature and humidity were monitored at 5 -min intervals for all barns by using HOBO Pro logger (Onset Computer Corp., Pocasset,
MA). Temperature-humidity index (THI) was calculated using the following equation: THI $=0.8 \times$ air temperature + [relative humidity $\times$ (air temperature - 14.4)] + 46.4 (McDowell et al., 1979). During the experimental period the average THI was $63.6 \pm 7.8$.

\section{Sample Collection}

Feed ingredients and TMR samples were obtained weekly and analyzed for DM content (AOAC International, 1995a) by drying for $24 \mathrm{~h}$ in a forced-air oven at $110^{\circ} \mathrm{C}$. Corn silage was sampled for DM twice weekly and inclusion was adjusted weekly based on DM content. Dietary DM was adjusted weekly for changes in feed ingredient DM content. Samples of TMR were taken weekly and stored at $-20^{\circ} \mathrm{C}$ until submitted for analysis. Samples of TMR, refused TMR, and corn silage were sieved with the Penn State Particle Separator (Nasco, Fort Atkinson, WI) weekly for to determine particle size distribution (Kononoff et al., 2003).

Weekly TMR and corn silage samples were analyzed for contents of DM, CP, soluble protein (SP), ADF, $\mathrm{NDF}$, lignin, starch, fat, ash, NFC, Ca, P, Mg, K, Na, $\mathrm{Fe}, \mathrm{Zn}, \mathrm{Cu}, \mathrm{Mn}, \mathrm{Mo}$, and $\mathrm{S}$ using wet chemistry methods (Schalla et al., 2012) at a commercial laboratory (Rock River Lab, Watertown, WI). Values for relative feed value, TDN, $\mathrm{NE}_{\mathrm{L}}, \mathrm{NE}_{\mathrm{M}}, \mathrm{NE}_{\mathrm{G}}, \mathrm{ME}$, and digestible energy were provided by the laboratory using calculations based on NRC (2001). Additionally, corn silage was analyzed for mycotoxins [15-acetyl deoxynivalenol, 3-acetyl deoxynivalenol, aflatoxin $\mathrm{B} 1$, aflatoxin $\mathrm{B} 2$, aflatoxin G1, aflatoxin G2, citrinin (AOAC International, 2000); deoxyscirepenol, diacetoxyscirpenol (MacDonald et al., 2005b); fumonisin B1, fumonisin B2, fumonisin B3, fusarenon X, HT-2 neosolaniol, nivalenol (Visconti et al., 2001); ochratoxin A (AOAC International, 2002); T-2 toxin (Croteau et al., 1994); and zearalenone (MacDonald et al., 2005a)] at a commercial laboratory (Rock River Lab).

Fermentation products (lactic acid, acetic acid, propionic acid, butyric acid, succinic acid, formic acid, ethanol, and ammonia N) were extracted at a commercial laboratory (Rock River Lab). Briefly, samples were diluted (1:10) with deionized water. The extract was centrifuged $\left(750 \times g\right.$ for $30 \mathrm{~min}$ at $\left.25^{\circ} \mathrm{C}\right)$ and supernatant was combined with calcium hydroxide and copper sulfate, centrifuged again, and the supernatant was analyzed by HPLC equipped with a reverse-phase ion exclusion column and a refractive index detector. The same laboratory performed the 30-h NDF digestibility analysis using a standardized in vitro rumen procedure. Fiber digestion was determined by difference in fiber content between intact and digested samples after $30 \mathrm{~h}$. 
On d 4 of wk 5 , individual TMR and fecal samples were taken and composited by treatments for measurement of apparent total-tract starch digestibility at a commercial laboratory (Rock River Lab). Briefly, the total-tract digestibility method was described by Lopes et al. (2009) and Schalla et al. (2012). Indigestible 120$\mathrm{h}$ iNDF (percentage of DM) was measured on TMR and fecal samples and used as an internal marker to calculate apparent starch digestibility. Sample iNDF was determined using an in vitro method (Goeser et al., 2009). Apparent total-tract starch digestibility was calculated using the following equation: Percentage apparent starch digestibility $=100-\{100 \times(\mathrm{TMR}$ iNDF $/$ fecal iNDF) $\times$ [fecal starch content (percentage of DM)/TMR starch content (percentage of DM)]\}. Refusals from each cow were measured and DMI was recorded daily.

Cows were milked 3 times daily at 0600, 1400, and $2100 \mathrm{~h}$. Milk weights were recorded daily and samples were obtained from the 3 consecutive milkings on $\mathrm{d} 2$ and 4 of wk 5. Samples were composited in proportion to milk yield at each sampling and preserved (800 Broad Spectrum Microtabs II; D\&F Control Systems Inc., San Ramon, CA). Composite milk samples were analyzed for fat, protein, lactose, urea N, TS, and SCC using mid-infrared procedures (AOAC International, 1995b) at a commercial laboratory (Dairy Lab Services, Dubuque, IA). Feed conversion calculations were completed for actual milk/DMI, ECM/DMI, and FCM/ DMI feed conversions.

Fecal score (FS) and general appearance (GA) were recorded daily. Fecal score was classified as follows: $1=$ runny: liquid consistency, splatters on impact, spreads readily; 2 = loose: may pile slightly and spreads and splatters moderately on impact and setting; $3=$ soft: firm but not hard, piles but spreads slightly on impact and settling; and $4=$ dry: hard, dry appearance, original form not distorted on impact and settling. Cows with FS $\leq 2$ were classified as experiencing transient digestive problems; whereas, cows with FS $>2$ were classified as healthy. For GA the scores were $1=$ bright and alert; 2 = depressed; and $3=$ reluctant to rise. Cows with GA $\geq 2$ were classified as sick; whereas, cows with GA $<2$ were classified as healthy.

Body weight was measured and BCS was assigned in quarter-unit increments (Ferguson et al., 1994) for each cow weekly. More than one individual assigned BCS independently at each time of scoring throughout the experiment. Lameness scores (LS) were assigned to all cows once weekly according to a visual locomotion scoring system with a 5 -point scoring system where 1 $=$ normal, $2=$ slightly irregular or asymmetrical gait, 3 $=$ favoring of one or more limb, $4=$ severely lame, and
$5=$ extremely lame (Bicalho et al., 2007). The animal was considered lame if the LS was $\geq 2$.

Blood was sampled from the tail vein or artery from each cow at $2 \mathrm{~h}$ postfeeding in wh 1 and 5 of each period. Samples were centrifuged $(959 \times g$ for $15 \mathrm{~min}$ at $4^{\circ} \mathrm{C}$ ) and serum was frozen at $-20^{\circ} \mathrm{C}$ within $2 \mathrm{~h}$ of blood collection. Commercially available kits were used to analyze the samples for urea $\mathrm{N}$ and glucose. Urea $\mathrm{N}$ was measured using the QuantiChrom Urea Assay kit (BioAssay Systems, Hayward, CA) and glucose was measured using the glucose autokit (Wako Diagnostics, Richmond, VA).

Cow activity was monitored using the HOBO pendant G logger (Hobo Pendant G Acceleration Data Logger, Onset Computer Corp.) attached laterally to the distal left hind leg. The activity monitor measured standing and lying behavior as validated by Ledgerwood et al. (2010). The activity logger was attached to the leg using vet wrap. Loggers were set to record at a 60-s interval. Data collected were then used to calculate lying time, bouts (per $24 \mathrm{~h}$ ), and duration of each bout, as well as standing time, bouts (per $24 \mathrm{~h}$ ), and duration of each bout.

Corn silage aerobic stability was measured using temperature data loggers (Maxim Integrated, San Jose, Ca) set to record the temperature at a 5-min logging interval. Data loggers were placed into buckets with $500 \mathrm{~g}$ of a representative sample from each treatment. Corn silage samples were taken immediately before feeding and were aerated before they were placed into the buckets. Three loggers were placed in each bucket, and buckets were kept at ambient daily temperature. One logger was placed outside the bucket to monitor environmental temperature, which was used as a covariate. This procedure was repeated 4 times (5 replicates per time), and each time the temperature was logged for $38 \mathrm{~h}$.

Corn silage density was also measured 2 times weekly throughout the experiment (10 wk). Density was measured using a forage probe attached to a drill (Dairy One, Ithaca, NY). Density was sampled from 5 areas of each treatment silo bag (upper left, upper right, center, lower left, and lower right). Samples were weighed and dried to obtain the DM and then density was calculated $\left(\mathrm{kg} / \mathrm{m}^{3}\right)$.

\section{Statistical Analysis}

Data from wk 5 was used for treatment inferences and daily measurements for DMI, milk yield, and milk components were reduced to weekly means before statistical analysis. Statistical analysis was performed us- 
ing SAS (ver. 9.4, SAS Institute Inc., Cary, NC). Mixed models were created using the MIXED procedure in SAS to analyze DMI, BCS, BW, milk yield, milk components, feed conversion, serum metabolites, and TMR apparent total-tract digestibility (starch). The model contained the fixed effects of treatment, covariate, and block; cow was the experimental unit and was analyzed as a random variable. For all variables, wk -1 was used as a covariate and values for wk 5 were analyzed. Corn silage quality, aerobic stability, and density descriptive values are presented. Basal diet (TMR) mean particle size and $\log 10$ standard deviation were calculated (Waldo et al., 1971). Activity data were first categorized into standing duration, standing time, standing bouts, lying duration, lying time, and lying bouts using SAS. These parameters were then analyzed using a mixed model with treatment being considered a fixed effect and cow was treated as a random effect. Three predetermined orthogonal contrasts were used. One contrast compared CON with all (1X, $2 \mathrm{X}$, or $3 \mathrm{X})$ corn silage with fungicide application, the second contrast was to determine linear effects, and the third was to determine quadratic effects of the treatments. Both linear and quadratic contrasts included CON. These contrasts were performed for all variables analyzed unless otherwise stated. Lameness scores were analyzed as a binomial distribution (lame or healthy) using the GLIMMIX procedure in SAS.

The degrees of freedom method was Kenward-Rogers (Littell et al., 1998). Residual distribution was evaluated for normality and homoscedasticity; extreme outliers were deleted for feed conversion $(\mathrm{n}=2)$, BCS $(\mathrm{n}=$ 1), ECM $(\mathrm{n}=2)$ and FCM $(\mathrm{n}=2)$ conversion, mold $(\mathrm{n}=1)$, acetic acid $(\mathrm{n}=1)$, lying bouts $(\mathrm{n}=2)$, and standing bouts $(\mathrm{n}=2)$. The data for SCC, yeast, mold, and serum urea nitrogen were log-transformed to meet criteria for normality and homoscedasticity. Statistical significance was declared at $P$-values lower than 0.05 , and a tendency was declared at $P$-values lower than 0.10 .

\section{RESULTS}

Signs of foliar disease were not observed when measured before each fungicide application. Whole-plant corn yield was $61.12 \mathrm{t} /$ ha for CON, $59.70 \mathrm{t} / \mathrm{ha}$ for $1 \mathrm{X}$, $63.99 \mathrm{t} / \mathrm{ha}$ for $2 \mathrm{X}$, and $61.22 \mathrm{t} / \mathrm{ha}$ for $3 \mathrm{X}$. Results of disease severity evaluations were nonexistent (signs not present) for all plants from all treatments at both time points, indicating either no disease was present or an extremely low presence of disease (below lower limit of detection).

\section{Corn Silage Quality}

Analyzed nutrients and content of lactic acid and $\mathrm{pH}$ in corn silage from each week of the experimental period are in Table 2 . The mean corn silage density was $187.2,187.2,200.7$, and $197 \mathrm{~kg} / \mathrm{m}^{3}$ for CON, $1 \mathrm{X}, 2 \mathrm{X}$, and $3 \mathrm{X}$, respectively. Corn silage temperatures after exposure to air for $38 \mathrm{~h}$ averaged $32.8,31.7,31.6$, and $28.8^{\circ} \mathrm{C}$ for CON, $1 \mathrm{X}, 2 \mathrm{X}$, and $3 \mathrm{X}$, respectively.

\section{Mycotoxins}

Three mycotoxins were present over the minimum detectable limits among treatments. During the trial 15-acetyl deoxynivalenol was found at a concentration of $0.1 \mathrm{mg} / \mathrm{kg}$ in CON, $1 \mathrm{X}$, and $2 \mathrm{X}$ silages, respectively. Deoxyscirepenol concentrations were $0.55,0.80,0.65$, and $0.40 \mathrm{mg} / \mathrm{kg}$ for CON, 1X, 2X, and $3 \mathrm{X}$, and zearalenone concentration was 60.3 and $51.8 \mu \mathrm{g} / \mathrm{kg}$ for CON and $1 \mathrm{X}$, respectively.

\section{Nutrient Composition of Basal Diet}

Analyzed nutrients from the last week of the experimental period are in Table 3. The particle size distribution of the basal diet as determined using the Penn State Particle Separator for pore size $19 \mathrm{~mm}$ was $6.2 \pm$ $1.4,6.8 \pm 4.0,6.6 \pm 2.1$, and $7.0 \pm 2.3 \%$; for pore size $7.8 \mathrm{~mm}$ was $40.1 \pm 4.0,41.9 \pm 4.1,41.4 \pm 2.0$, and 43.5 $\pm 2.1 \%$; for pore size $1.2 \mathrm{~mm}$ was $39.8 \pm 3.9,39.8 \pm$ $4.8,41.3 \pm 3.1$, and $39.5 \pm 2.7 \%$; and for pan was 13.9 $\pm 4.1,11.4 \pm 2.2,10.7 \pm 3.2$, and $9.9 \pm 2.1 \%$ for $\mathrm{CON}$, $1 \mathrm{X}, 2 \mathrm{X}$, and $3 \mathrm{X}$, respectively. The mean particle size of TMR for each treatment was 4,595, 5,009, 5,039, and $5,275 \mu \mathrm{m}$ for CON, 1X, 2X, and 3X, respectively. The $\log _{10}$ standard deviation of the mean particle size of TMR for each treatment was $0.48,0.47,0.46$, and 0.46 for CON, 1X, 2X, and 3X, respectively.

\section{Health, Fecal Scores, and Activity}

Cows had only minor incidence of being sick (GA $<2$ ), with cows being scored a number other than 3 only 17 times (from a total of 4,480 observations, $0.4 \%$ ) over the duration of the trial, with 1 cow $(\mathrm{CON})$ who was treated for fever with unknown cause accounting for 12 counts. The mean GA was 1.03, 1.00, 1.22, and 1.12 for CON, 1X, 2X, and 3X, respectively. Treatment CON was not different from the average of cows fed silage treated with the foliar fungicide [odds ratio $(\mathbf{O R})$ $=1.008 ; 95 \% \mathrm{CI}=0.85$ to $1.16 ; P=0.90]$. The mean FS was 2.91, 2.96, 2.72, and 2.86 for CON, 1X, 2X, 
and 3X, respectively. Fecal scores were not different between cows fed CON silage when compared with the average of cows receiving corn silage treated with foliar fungicide $(\mathrm{OR}=1.06 ; 95 \% \mathrm{CI}=0.81$ to $1.08 ; P=$ $0.30)$. The mean for LS was $1.32,1.29,1.19$, and 1.15 for CON, 1X, 2X, and 3X, respectively. Lameness score tended to be higher for cows receiving the CON silage when compared with the average of cows receiving the treated silage $(\mathrm{OR}=0.40 ; 95 \% \mathrm{CI}=0.69$ to $9.07 ; P$ $=0.06)$. It was also observed that cows fed corn silage treated with fungicide tended to have a shorter duration of time spent lying when compared with control $(P$ $=0.10 ;$ Table 4 ).

\section{Intake, BW, and BCS}

A linear treatment effect for DMI was observed, with DMI decreasing as foliar fungicide applications in- creased $(P=0.002$; Table 5$)$. A tendency was observed $(P=0.08)$ for cows consuming corn silage treated with fungicide to consume less DM than those consuming CON. No differences were observed for BW $(P=0.50)$ and $\mathrm{BCS}(P=0.87$; Table 5$)$.

\section{Milk Production and Feed Conversion}

Milk yield was similar for CON when compared with all treatments containing corn silage treated with fungicide $(P=0.90$; Table 5$)$. No quadratic or linear effects for milk yield $(P=0.94$ and $P=0.86$, respectively), $3.5 \% \operatorname{FCM}(P=0.73$ and $P=0.69$, respectively $)$, and $\operatorname{ECM}(P=0.73$ and $P=0.67$, respectively) were observed among treatments. Milk composition did not differ between CON and the average of the corn silages treated with fungicide $(P>0.13)$. A tendency for a treatment linear effect was observed for SCC, with cows

Table 2. Mean chemical composition (\% of DM unless otherwise noted) and standard deviation of nutrient composition, fermentation profile, energy content, and microbial count of corn silage treated with no applications of foliar fungicide (CON), 1 application of foliar fungicide (1X), 2 applications of foliar fungicide (2X), or 3 applications of foliar fungicide (3X)

\begin{tabular}{|c|c|c|c|c|c|}
\hline \multirow[b]{2}{*}{ Item } & \multicolumn{4}{|c|}{ Treatment $^{1}$} & \multirow[b]{2}{*}{$\mathrm{SD}^{2}$} \\
\hline & $\mathrm{CON}$ & $1 \mathrm{X}$ & $2 \mathrm{X}$ & $3 \mathrm{X}$ & \\
\hline \multicolumn{6}{|l|}{ Corn silage composition } \\
\hline $\mathrm{DM}, \%$ as fed & 30.63 & 30.98 & 34.41 & 30.37 & 1.68 \\
\hline $\mathrm{CP}$ & 8.61 & 8.72 & 8.50 & 8.98 & 0.81 \\
\hline NDF & 47.32 & 45.88 & 45.41 & 45.28 & 3.89 \\
\hline NDF digestibility, $30 \mathrm{~h}$ & 50.09 & 49.67 & 49.00 & 48.82 & 6.20 \\
\hline $\mathrm{ADF}$ & 29.24 & 27.72 & 28.11 & 27.33 & 2.34 \\
\hline Fat & 2.71 & 2.77 & 2.74 & 3.16 & 0.48 \\
\hline Lignin & 3.45 & 3.65 & 3.36 & 3.22 & 1.13 \\
\hline Soluble CP, $\%$ of CP & 56.18 & 51.98 & 54.05 & 59.04 & 4.17 \\
\hline Starch & 27.61 & 28.67 & 29.26 & 28.70 & 3.30 \\
\hline Sugar & 0.72 & 1.14 & 1.23 & 1.25 & 0.27 \\
\hline Ash & 5.11 & 4.92 & 4.79 & 4.76 & 0.39 \\
\hline $\mathrm{Ca}$ & 0.22 & 0.22 & 0.20 & 0.22 & 0.01 \\
\hline $\mathrm{P}$ & 0.19 & 0.19 & 0.18 & 0.19 & 0.01 \\
\hline $\mathrm{Mg}$ & 0.14 & 0.13 & 0.13 & 0.14 & 0.01 \\
\hline $\mathrm{K}$ & 1.34 & 1.27 & 1.21 & 1.24 & 0.09 \\
\hline $\mathrm{S}$ & 0.10 & 0.10 & 0.09 & 0.10 & 0.01 \\
\hline \multicolumn{6}{|l|}{ Energy calculations $^{3}$} \\
\hline TDN & 65.55 & 65.92 & 66.54 & 67.37 & 2.20 \\
\hline $\mathrm{NE}_{\mathrm{L}}, \mathrm{Mcal} / \mathrm{kg}$ & 1.43 & 1.43 & 1.45 & 1.48 & 0.02 \\
\hline $\mathrm{NE}_{\mathrm{G}}, \mathrm{Mcal} / \mathrm{kg}$ & 0.97 & 0.99 & 1.01 & 1.04 & 0.04 \\
\hline $\mathrm{NE}_{\mathrm{M}}, \mathrm{Mcal} / \mathrm{kg}$ & 1.58 & 1.58 & 1.61 & 1.65 & 0.04 \\
\hline \multicolumn{6}{|l|}{ Fermentation products } \\
\hline $\mathrm{pH}$ & 4.88 & 4.99 & 4.99 & 4.84 & 0.30 \\
\hline Lactic acid & 4.91 & 4.25 & 4.63 & 4.65 & 2.05 \\
\hline Acetic acid & 2.97 & 2.78 & 1.31 & 3.47 & 0.94 \\
\hline Ethanol & 0.20 & 0.21 & 0.16 & 0.32 & 0.17 \\
\hline Ammonia N & 0.08 & 0.07 & 0.06 & 0.09 & 0.02 \\
\hline \multicolumn{6}{|l|}{ Microbial count } \\
\hline Yeast, cfu/g & 2,663 & 1,741 & 50,595 & 5,153 & 94,001 \\
\hline Mold, cfu/g & 92,800 & 14,300 & 51,541 & 72,300 & 30,750 \\
\hline
\end{tabular}

${ }^{1}$ Treatment $=$ control diet $(\mathrm{CON}$, with no application of fungicide), $1 \mathrm{X}$ (with 1 application), $2 \mathrm{X}$ (with 2 applications), and 3X (with 3 applications).

${ }^{2}$ Maximum within treatment SD.

${ }^{3}$ NRC (2001). 
Table 3. Mean chemical composition (\% of DM unless otherwise noted) and standard deviation of diet fed to cows receiving corn silage treated with no applications of foliar fungicide $(\mathrm{CON}), 1$ application of foliar fungicide (1X), 2 applications of foliar fungicide (2X), or 3 applications of foliar fungicide (3X) throughout the experiment

\begin{tabular}{|c|c|c|c|c|c|}
\hline \multirow[b]{2}{*}{ Item } & \multicolumn{4}{|c|}{ Treatment $^{1}$} & \multirow[b]{2}{*}{$\mathrm{SD}^{2}$} \\
\hline & $\mathrm{CON}$ & $1 \mathrm{X}$ & $2 \mathrm{X}$ & $3 \mathrm{X}$ & \\
\hline $\mathrm{DM}, \%$ & 50.71 & 50.05 & 49.27 & 48.7 & 1.15 \\
\hline $\mathrm{CP}$ & 15.27 & 15.53 & 15.77 & 16.10 & 1.05 \\
\hline $\mathrm{ADF}$ & 17.97 & 18.37 & 17.90 & 19.74 & 2.21 \\
\hline $\mathrm{NDF}$ & 35.45 & 36.35 & 36.18 & 39.31 & 2.92 \\
\hline Lignin & 1.98 & 2.01 & 1.72 & 2.04 & 0.39 \\
\hline Starch & 29.18 & 28.79 & 30.59 & 28.20 & 2.54 \\
\hline Sugar & 1.47 & 1.50 & 1.46 & 1.89 & 0.48 \\
\hline Crude fat & 4.59 & 4.62 & 4.61 & 5.97 & 0.68 \\
\hline Ash & 8.07 & 7.89 & 9.28 & 7.94 & 0.71 \\
\hline $\mathrm{TDN}^{3}$ & 74.0 & 73.5 & 70.0 & 71.0 & 2.70 \\
\hline $\mathrm{NE}_{\mathrm{L}},{ }^{3} \mathrm{Mcal} / \mathrm{kg}$ & 1.76 & 1.74 & 1.65 & 1.67 & 0.06 \\
\hline $\mathrm{Ca}$ & 1.21 & 1.04 & 1.60 & 1.20 & 0.06 \\
\hline $\mathrm{P}$ & 0.35 & 0.35 & 0.39 & 0.37 & 0.01 \\
\hline $\mathrm{Mg}$ & 0.26 & 0.26 & 0.39 & 0.28 & 0.23 \\
\hline K & 1.14 & 1.22 & 1.30 & 1.28 & 0.08 \\
\hline $\mathrm{Na}$ & 0.37 & 0.39 & 0.43 & 0.42 & 0.04 \\
\hline $\mathrm{S}$ & 0.21 & 0.22 & 0.24 & 0.22 & 0.01 \\
\hline $\mathrm{Fe}, \mathrm{mg} / \mathrm{kg}$ & 517 & 469.5 & 682 & 472 & 97.3 \\
\hline $\mathrm{Zn}, \mathrm{mg} / \mathrm{kg}$ & 86 & 84.5 & 98.5 & 92.5 & 7.12 \\
\hline $\mathrm{Cu}, \mathrm{mg} / \mathrm{kg}$ & 15.5 & 15.5 & 18.5 & 16.5 & 0.87 \\
\hline $\mathrm{Mn}, \mathrm{mg} / \mathrm{kg}$ & 73.0 & 70.5 & 87.0 & 78.5 & 3.92 \\
\hline $\mathrm{Mo}, \mathrm{mg} / \mathrm{kg}$ & 0.90 & 0.80 & 0.95 & 0.80 & 0.14 \\
\hline
\end{tabular}

${ }^{1}$ Treatment $=$ control diet $(\mathrm{CON}$, with no application of fungicide), $1 \mathrm{X}$ (with 1 application), $2 \mathrm{X}$ (with 2 applications), and 3X (with 3 applications).

${ }^{2}$ Maximum within treatment SD.

${ }^{3} \mathrm{NRC}(2001)$

receiving more applications of foliar fungicide having lower SCC $(P=0.09)$.

All cows fed corn silage treated with fungicide tended to have higher FCM conversion $(P=0.09)$ and ECM conversion $(P=0.08)$ than CON (Table 5). A linear treatment effect was observed for $3.5 \% \mathrm{FCM}$ conversion, ECM conversion, and milk yield feed conversion $(P<0.03)$. Cows fed corn silage with more applications of foliar fungicide tended to have higher feed conversion than those fed CON ( $P=0.08$; Table 5$)$.

\section{Apparent Total-Tract Starch Digestibility}

Apparent total-tract digestibility did not differ for starch $(P>0.63)$ between CON $(92.8 \%)$ and corn silage treated with fungicide $(93.9,85.5$, and $93.6 \%$ for

Table 4. Least squares means and associated standard error for standing and lying behavior for cows fed corn silage treated with no foliar fungicide (CON), 1 application of foliar fungicide (1X), 2 applications of foliar fungicide (2X), or 3 applications of foliar fungicide (3X)

\begin{tabular}{|c|c|c|c|c|c|c|c|c|}
\hline Item & \multicolumn{4}{|c|}{ Treatment $^{1}$} & SEM & \multicolumn{3}{|c|}{$P$-value ${ }^{2}$} \\
\hline Standing bouts, no. ${ }^{3}$ & 11.0 & 12.2 & 13.6 & 11.0 & 1.1 & 0.44 & 0.81 & 0.15 \\
\hline Lying time, min & 738.0 & 730.8 & 699.9 & 647.8 & 38.5 & 0.38 & 0.12 & 0.62 \\
\hline Lying duration, min & 62.4 & 51.6 & 55.4 & 55.7 & 3.7 & 0.10 & 0.39 & 0.19 \\
\hline
\end{tabular}

${ }^{1}$ Treatment $=$ control corn silage (CON, with no application of fungicide), 1X (with 1 application), 2X (with 2 applications), and 3X (with 3 applications).

${ }^{2}$ Contrasts were CON vs. TRT $=$ no fungicide application $(\mathrm{CON})$ with that of the average of the three treatments with fungicide application; linear = linear effect of treatment frequency; and quadratic = quadratic effect of treatment frequency.

${ }^{3}$ No. $=$ number of bouts $/ 24 \mathrm{~h}$. 
$1 \mathrm{X}, 2 \mathrm{X}$, and 3X, respectively; $\mathrm{SEM}=3.0)$. The linear $(P>0.69)$ and quadratic $(P>0.36)$ treatment effects were not present.

\section{Serum Metabolites}

Serum glucose concentrations for CON, 1X, 2X, and $3 \mathrm{X}$ were $63.4,48.6,49.2$, and $55.5 \mathrm{mg} / \mathrm{dL}$, respectively. All cows fed corn silage treated with fungicide had lower glucose concentrations than $\mathrm{CON}(P=0.001)$. A treatment quadratic effect for serum glucose concentration was observed $(P=0.0001$; Table 5$)$. No differences were observed $(P>0.52)$ for serum urea nitrogen.

\section{DISCUSSION}

The aim of this study was to determine the effects of corn silage produced from corn treated with various fungicide applications on lactating dairy cows. We postulated that corn silage produced from corn treated with fungicide might affect DMI, milk yield, and composition and efficiency of Holstein cows.

Overall, DMI decreased in cows fed corn silage treated with fungicide; however, cows maintained their milk production in comparison with $\mathrm{CON}$, leading to an overall increased feed conversion in cows fed corn silage treated with fungicide at least for the duration of the trial. Body weight and BCS did not differ between $\mathrm{CON}$ and corn silage treated with fungicide, so it does not appear that cows were using body stores to achieve this change in efficiency. However, if treatments were fed to cows during early lactation a difference in $\mathrm{BW}$ and BCS could have been seen at that stage, as DMI is pivotal in preventing excessive negative energy balance (Drackley, 2006).

Serum glucose concentration was lower for cows fed corn silage treated with fungicide when compared with CON, perhaps due to decreased DMI. However, Holcomb et al. (2001) did not report a difference in plasma glucose concentration for lactating cows fed free choice or restricted diets. Graugnard et al. (2012) reported that prepartum cows fed a high-energy diet had higher blood glucose concentration both prepartum and postpartum when compared with a controlled-energy diet (1.62 vs. $1.34 \mathrm{Mcal} / \mathrm{kg}$, respectively). It has also been shown that when blood cortisol concentrations were high, an indicator of stress, blood glucose concentration also increased due to the effects of cortisol as an insulin

Table 5. Least squares means and associated standard errors for DMI, milk parameters response, and serum metabolites of cows in (CON), 1 application of foliar fungicide (1X), 2 applications of foliar fungicide (2X), or 3 applications of foliar fungicide (3X)

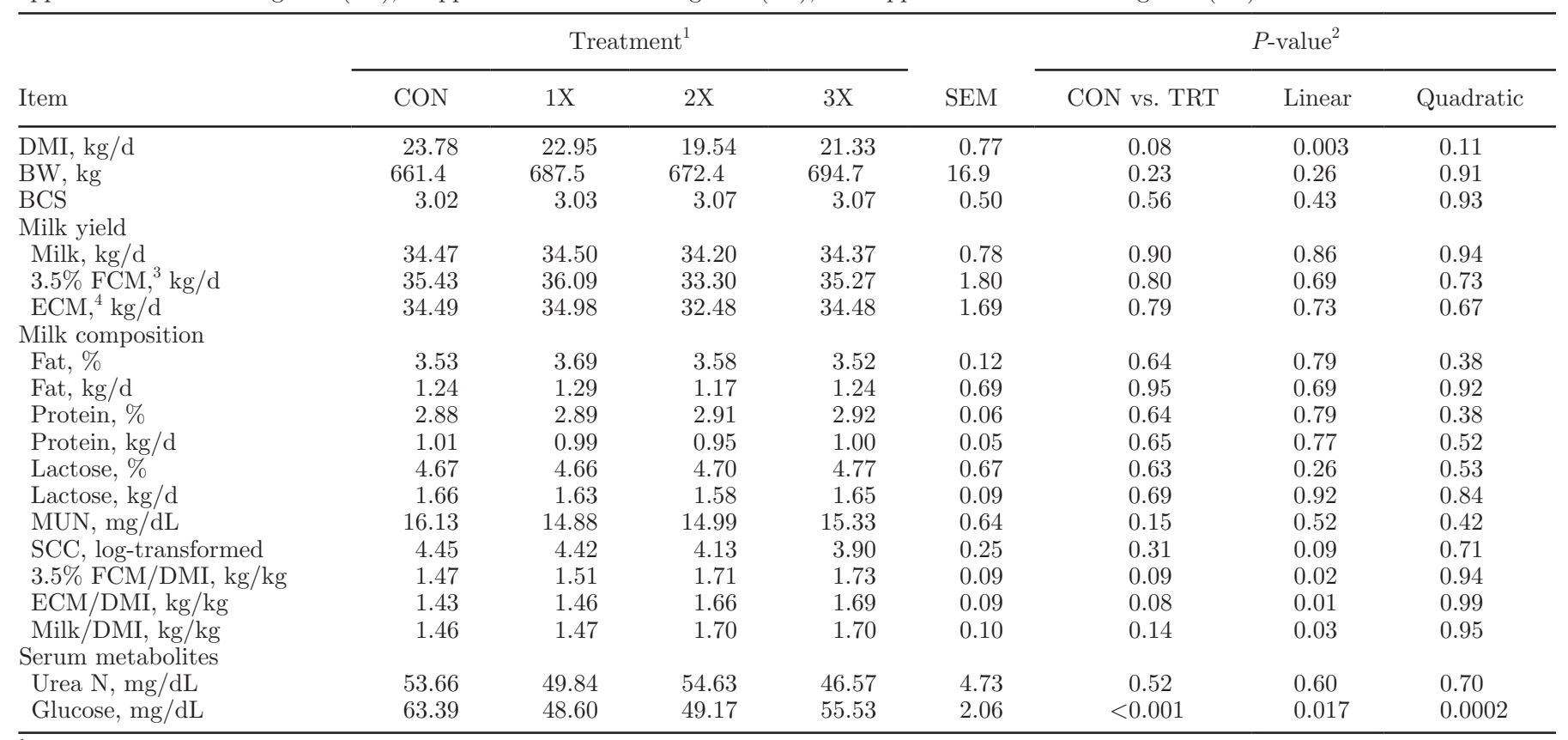

${ }^{1}$ Treatment $=$ control diet (CON, with no application of fungicide), 1X (with 1 application), $2 \mathrm{X}$ (with 2 applications), and 3X (with 3 applications).

${ }^{2}$ Contrasts were CON vs. TRT $=$ no fungicide application $(\mathrm{CON})$ with that of the average of the three treatments with fungicide application; linear $=$ linear treatment effect; and quadratic $=$ quadratic treatment effect.

${ }^{3} 3.5 \% \mathrm{FCM}=[(0.4255 \times$ milk yield $)+(16.425 \times$ milk fat yield $)]$.

${ }^{4} \mathrm{ECM}=[(12.82 \times$ milk fat yield $)+(7.13 \times$ milk protein yield $)+(0.323 \times$ milk yield $)]$. 
antagonist and due to reduced glucose use by peripheral tissues (Pechova and Pavlata, 2007). A trend was noted for longer lying duration for cows receiving CON. Little research has been done on the effect of lying duration on cow health and productivity, so few inferences can be made on why this occurred. However, it has been reported that the amount of time spent eating and the number of eating bouts are correlated with animal health (Huzzey et al., 2007).

One possible reason for why cows fed corn silage treated with fungicide may have had better feed conversion was the difference in amount of mycotoxins present in the corn silages. The main mycotoxins found were 15-acetyl deoxynivalenol, deoxyscirpenol, and zearalenone. These 3 mycotoxins are known to be produced by the Fusarium species of fungi. Although no visual observation of fungus was noted in the corn in the field, a study done by Eckard et al. (2011) concluded that when corn was diagnosed visually only 1 to $3 \%$ of corn showed signs of infection on the surface; however, when the corn particles were plated it was found that the average Fusarium incidence was $46 \%$. Corn harvested for our study could have been infected, even though visual symptoms were not present. Fungal contamination of corn silage can lead to DM loss, nutrient loss, and reduced palatability (Alonso et al., 2013).

It has also been reported that Fusarium concentrations of $1 \times 10^{4} \mathrm{cfu} / \mathrm{g}$ in forage can cause abnormal rumen fermentation (Scudamore and Livesey, 1998). This effect could be multiplied for cattle raised in intensive operations under any type of stress (Binder, 2007). The presence of these mycotoxins in the silage, although not considered to be at a harmful concentration, could lead to poorer rumen fermentation, leading to decreased nutrient availability and overall lower conversion. Even though the cows fed corn silage treated with fungicide had lower DMI, this could be due in part to the cows being able to use energy better due to better rumen function and, therefore, eat less while still maintaining the same milk production (Haerr, 2015).

Another potential explanation for lower feed conversion by cows in CON could be the higher aerobic stability of treated corn silages. Numerically, 3X had a lower temperature over the $38 \mathrm{~h}$. Fungi are the main organisms responsible for heat spoilage of corn silage, so fewer fungi in corn silage treated with fungicide could have contributed to higher aerobic stability (Williams et al., 1995). Density of corn silage is also a major contributor to aerobic stability and deterioration (Weinberg et al., 2011). The major purpose of high packing density is to reduce aerobic deterioration. If the packing is not done correctly, aerobic deterioration can actually begin in the bag (Pahlow et al., 2003). In our study, no appar- ent difference was noticed in packing density in any of the silages. However, as expected, packing density was lower in the beginning and increased throughout the trial. Additionally, numerically higher concentrations of ethanol in the $3 \mathrm{X}$ silage may have been related to its numerically higher sugar content, because ethanol is a main end product of sugar fermentation (Mcdonald et al., 1991). Overall, numerically increased sugar content may have contributed to a more nutrient dense, highquality feed.

It is widely known that high variation of NDF and NDF digestibility (NDFD) exists among different corn silages. This can be due to population density, hybrid difference, environmental growing conditions, or stressors (Allen et al., 2003). In our study, the aforementioned sources of variation were controlled. Neutral detergent fiber is often associated with the amount of DM that can be consumed due to the fact that it represents the total insoluble fiber matrix (Van Soest, 1994). Kendall et al. (2009) reported that a 4 percentage unit decrease in NDF (from 32 to $28 \%$ dietary NDF) increased feed intake $(22 \mathrm{~kg} / \mathrm{d}$ for high-NDF compared with $23 \mathrm{~kg} / \mathrm{d}$ for low-NDF diets), milk production by approximately $3 \mathrm{~kg} / \mathrm{d}$, milk fat by $0.1 \mathrm{~kg} / \mathrm{d}$, and milk protein by 0.15 $\mathrm{kg} / \mathrm{d}$ for cows fed the lower-NDF diet. However, DIM for cows in the aforementioned study was $38 \pm 15$, so the potential to increase intake was greater than the present study. When referencing to corn silage specifically, a one-unit increase in in vitro or in situ digestibility of corn silage NDF was associated with $0.25 \mathrm{~kg} / \mathrm{d}$ increase in 4\% FCM yield, respectively (Oba and Allen, 1999).

It seems that 30-h NDFD was similar between corn silage treated with fungicide and $\mathrm{CON}$; thus, even though the treated silage had numerically less NDF, the NDF had approximately the same digestibility potential for all 4 treatments. Lignin can be an indicator of cell wall and NDF digestibility (Van Soest, 1994), and the similar lignin contents may be a potential reason that 30-h NDFD was similar among all tested corn silages.

Collectively, the factors discussed could have been possible contributors to the overall higher TDN found in $3 \mathrm{X}$ when compared with CON. Although net energy for corn silage may be hard to calculate, and values may not be consistent, a numerically higher TDN found in the corn silage treated with fungicide may lead to higher feed conversion when fed to cattle. Although affected by other factors, energy intake can often help in determining overall cow performance (Allen et al., 2003). Weiss and Wyatt (2000) reported that an increase of $3 \%$ TDN in a high-oil corn silage led to greater $3.5 \%$ FCM (23.9 vs. $22.6 \mathrm{~kg} / \mathrm{d}$ ) when fed to dairy cattle at a $63 \%$ inclusion rate. 


\section{CONCLUSIONS}

Cows receiving silage treated with foliar fungicide had lower DMI but similar milk production as cows receiving the control silage, which resulted in higher feed conversion (milk/DMI, 3.5\% FCM/DMI, and ECM/DMI). Serum glucose was lower for cows receiving corn silage treated with fungicide compared with CON. Foliar fungicide treatment seems to be beneficial to corn silage quality and resulted in increased feed conversion when treated corn silage was fed to lactating dairy cows.

\section{REFERENCES}

Adee, E. A., L. E. Paul, E. D. Nafziger, and G. Bollero. 2005. Yield loss of corn hybrids to incremental defoliation. Crop Manag. 4:1-8.

Allen, M. S., J. G. Coors, and G. W. Roth. 2003. Corn silage. Pages 547-608 in Silage Science and Technology. D. R. Buxton, R. E. Muck, and J. H. Harrison, ed. American Society of Agronomy, Crop Science Society of America, Soil Science Society of America.

Alonso, V. A., C. M. Pereya, L. A. M. Keller, A. M. Dalcero, C. A. R. Rosa, S. M. Chiacchiera, and L. R. Cavaglieri. 2013. Fungi and mycotoxins in silage: An overview. J. Appl. Microbiol. 115:637-643.

AOAC International. 1995a. AOAC official method 934.01. Moisture in animal feed. Pages 23-26 in Official Methods of Analysis. 16th ed. Vol. 2. AOAC International, Arlington, VA.

AOAC International. 1995b. AOAC official method 972.16. Fat, lactose, protein, and solids in milk. Mid-infrared spectroscopic method. Pages 23-26 in Official Methods of Analysis. 16th ed. Vol. 2. AOAC International, Arlington, VA.

AOAC International. 2000. AOAC official method 972.16. Aflatoxins in corn, almonds, brazil nuts, peanuts, and pistachio nuts. Multifunctional column (mycosep) method. Pages 26-27 in Official Methods of Analysis. 17th ed. Vol. 2. AOAC International, Arlington, VA.

AOAC International. 2002. AOAC Official Method 2000.03. Ochratoxin A in corn and barley. Liquid chromatographic method. Official Methods of Analysis of AOAC Int. 18th ed. Vol 18. AOAC International, Madison, WI.

Bal, M., R. Shaver, K. Shinners, J. Coors, J. Lauer, R. Straub, and R. Koegel. 2000. Stage of maturity, processing, and hybrid effects on ruminal in situ disappearance of whole-plant corn silage. Anim. Feed Sci. Technol. 86:83-94.

Bicalho, R. C., S. H. Cheong, G. G. Cramer, and C. L. Guard. 2007. Association between a visual and an automated locomotion score in lactating Holstein cows. J. Dairy Sci. 90:3294-3300.

Binder, E. M. 2007. Managing the risk of mycotoxins in modern feed production. Anim. Feed Sci. Technol. 133:149-166.

Croteau, S. M., D. B. Prelusky, and H. L. Trenholm. 1994. Analysis of trichothecene mycotoxins by gas chromatography with electron capture detection. J. Agric. Food Chem. 42:928-933.

dos Santos, V. M., J. W. Dorner, and F. Carreira. 2003. Isolation and toxigenicity of Aspergillus fumigatus from moldy silage. Mycopathologia 156:133-138.

Drackley, J. K. 2006. Advances in transition cow biology: New frontiers in production diseases. Pages 24-34 in Production Diseases in Farm Animals. Proc. 12th Int. Conf. N. Joshi and T. H. Herdt, ed. Wageningen Academic Publishers, Wageningen, the Netherlands.

Eckard, S., F. E. Wettstein, F. Hans-Rudolf, and S. Vogelgsang. 2011. Incidence of Fusarium species and mycotoxins in silage maize. Toxins (Basel) 3:949-967.

FASS. 2010. Guide for the Care and Use of Agricultural Animals in Agricultural Research and Teaching. Federation of Animal Science Societies, Champaign, IL.
Ferguson, J. D., D. T. Galligan, and N. Thomsen. 1994. Principal descriptors of body condition score in Holstein cows. J. Dairy Sci. 77:2695-2703.

Ferraretto, L. F., and R. D. Shaver. 2012. Meta-analysis: Impact of corn silage harvest practices on intake, digestion and milk production by dairy cows. Prof. Anim. Sci. 28:141-149.

Goeser, J. P., P. C. Hoffman, and D. K. Combs. 2009. Modification of a rumen fluid priming technique for measuring in vitro neutral detergent fiber digestibility. J. Dairy Sci. 92:3842-3848.

Graugnard, D. E., M. Bionaz, E. Trevisi, K. M. Moyes, J. L. SalakJohnson, R. L. Wallace, J. K. Drackley, G. Bertoni, and J. J. Loor. 2012. Blood immunometabolic indices and polymorphonuclear neutrophil function in peripartum dairy cows are altered by level of dietary energy prepartum. J. Dairy Sci. 95:1749-1758.

Haerr, K. 2015. Use of corn treated with various applications of foliar fungicide to increase corn silage quality and performance of Holstein cows. MS Thesis. University of Illinois, Urbana.

Holcomb, C. S., H. H. Van Horn, H. H. Head, M. B. Hall, and C. J. Wilcox. 2001. Effects of prepartum dry matter intake and forage percentage on postpartum performance of lactating dairy cows. J. Dairy Sci. 84:2051-2058.

Huzzey, J. M., F. M. Veira, D. M. Weary, and M. A. G. von Keyserlingk. 2007. Prepartum behavior and dry matter intake identify dairy cows at risk for metritis. J. Dairy Sci. 90:3220-3233.

Kendall, C., C. C. Leonardi, P. C. Hoffman, and D. K. Combs. 2009. Intake and milk production of cows fed diets that differed in dietary neutral detergent fiber and neutral detergent fiber digestibility. J. Dairy Sci. 92:313-323.

Kononoff, P. J., A. J. Heinrichs, and D. R. Buckmaster. 2003. Modification of the Penn State Forage and total mixed ration particle separator and the effects of moisture content on its measurements. J. Dairy Sci. 86:1858-1863.

Ledgerwood, D. N., C. Winckler, and C. B. Tucker. 2010. Evaluation of data loggers, sampling intervals, and editing techniques for measuring the lying behavior of dairy cattle. J. Dairy Sci. 93:5129-5139.

Littell, R. C., P. R. Henry, and C. B. Ammerman. 1998. Statistical analysis of repeated measures data using SAS procedures. J. Anim. Sci. 76:1216-1231.

Lopes, J. C., R. D. Shaver, P. C. Hoffman, M. S. Akins, S. J. Bertics, H. Gencoglu, and J. G. Coors. 2009. Type of corn endosperm influences nutrient digestibility in lactating dairy cows. J. Dairy Sci. 92:4541-4548.

MacDonald, S. J., S. Anderson, P. Brereton, R. Wood, and A. Damant. 2005a. Determination of zearalenone in barley, maize and wheat flour, polenta, and maize-based baby food by immunoaffinity column cleanup with liquid chromatography: Interlaboratory study. J. AOAC Int. 88:1733-1740.

MacDonald, S. J., D. Chan, P. Brereton, A. Damant, and R. Wood. 2005b. Determination of deoxynivalenol in cereals and cereal products by immunoaffinity column cleanup with liquid chromatography: Interlaboratory study. J. AOAC Int. 88:1197-1204.

Mcdonald, P., A. R. Henderson, and S. J. E. Heron. 1991. The Biochemistry of Silage. 2nd ed. Chalcombe Publications, Marlow, UK.

McDowell, D., N. Hooven, and K. Cameron. 1979. Effects of climate on performance of Holsteins in first lactation. J. Dairy Sci. 59:965971

Mueller, D., and R. Pope. 2009. Corn Field Guide. Iowa State University, Extension and Outreach. Ames, IA.

NRC. 2001. Nutrient Requirements of Dairy Cattle. 7th rev. ed. Natl. Acad. Sci., Washington, DC.

Oba, M., and M. S. Allen. 1999. Evaluation of the importance of the digestibility of neutral detergent fiber from forage: Effects on dry matter intake and milk yield of dairy cows. J. Dairy Sci. 82:589596.

Pahlow, G., R. E. Muck, F. Driehuis, S. J. W. H. O. Elferink, and S. F. Spoelstra. 2003. Microbiology of ensiling. Pages 31-93 in Silage Science and Technology. D. R. Buxton, R. E. Muck, and J. H. Harrison, ed. American Society of Agronomy, Crop Science Society of America, Soil Science Society of America, Madison, WI. 
Paul, P. A., L. V. Madden, C. A. Bradley, A. E. Robertson, G. P. Munkvold, G. Shaner, K. A. Wise, D. K. Malvick, T. W. Allen, A. Grybauskas, P. Vincelli, and P. Esker. 2011. Meta-analysis of yield response of hybrid field corn to foliar fungicides in the US corn belt. Phytopathology 101:1122-1132.

Pechova, A., and L. Pavlata. 2007. Chromium as an essential nutrient: A review. Vet. Med. (Praha) 52:1-18.

Richard, E., N. Heutte, L. Sage, D. Pottier, V. Bouchart, P. Lebailly, and D. Garon. 2007. Toxigenic fungi and mycotoxins in mature corn silage. Food Chem. Toxicol. 45:2420-2425.

Schalla, A., L. Meyer, Z. Meyer, S. Onetti, A. Schultz, and J. Goeser. 2012. Hot topic: Apparent total-tract nutrient digestibilities measured commercially using 120-hour in vitro indigestible neutral detergent fiber as a marker are related to commercial dairy cattle performance. J. Dairy Sci. 95:5109-5114.

Scudamore, K. A., and C. T. Livesey. 1998. Occurrence and significance of of mycotoxins in forage crops and silage: a review. J. Sci Food Agric. 77:1-17.

Teller, R. S., R. J. Schmidt, L. W. Whitlow, and L. Kung Jr.. 2012. Effect of physical damage to ears of corn before harvest and treatment with various additives on the concentration of mycotoxins, silage fermentation, and aerobic stability of corn silage. J. Dairy Sci. 95:1428-1436.

Van Soest, P. J. 1994. Nutritional Ecology of the Ruminant. Cornell University Press, Ithaca, NY.

Venancio, W. S., M. A. T. Rodrigues, E. Begliomini, and N. L. de Souza. 2009. Physiological effects of strobilurin fungicides on plants. Cienc. Exatas Terra Cienc. Agrar. Eng. 9:59-68.
Visconti, A., M. Solfrizzo, and A. De Girolamo. 2001. Determination of fumonisins B1 and B2 in corn and corn flakes by liquid chromatography with immunoaffinity column cleanup: Collaborative study. J. AOAC Int. 84:1828-1837.

Waldo, D. R., L. W. Smith, E. L. Cox, B. T. Weinland, and H. L. Lucas Jr.. 1971. Logarithmic normal distribution for description of sieved forage materials. J. Dairy Sci. 10:1465-1469.

Ward, J. M. J., M. D. Laing, and D. C. Nowell. 1997. Chemical control of maize grey leaf spot. Crop Prot. 16:265-271.

Weinberg, Z.G., P. Khanal, C. Yildiz, Y. Chen, and A. Arieli. 2011. Ensiling fermentation products and aerobic stability of corn and sorghum silages. Grassl. Sci. 57:46-50.

Weiss, W. P., and D. Wyatt. 2000. Effect of oil content and kernel processing of corn silage on digestibility and milk production by dairy cows. J. Dairy Sci. 83:351-358.

Williams, A. G., D. L. Critten, and A. M. Reynolds. 1995. A mathematical model of the aerobic deterioration of silage. Grass Forage Sci. 50:132-146.

Wise, K., and D. Mueller. 2011. Are fungicides no longer just for fungi? An analysis of foliar fungicide use in corn. APSnet Features. http://dx.doi.org/10.1094/APSnetFeature-2011-0531.

Yates, I. E., C. W. Bacon, and D. M. Hinton. 1997. Effects of endophytic infection by Fusarium moniliforme on corn growth and cellular morphology. Plant Dis. 81:723-728. 